
\title{
3 Research Square \\ Experimental Study on Different Phytoremediation of Heavy Metal Pollution in High-Density Sludge Sediment of Copper Mines
}

\section{Ruoyan Cai}

School of Energy and Mechanical Engineering, Jiangxi University of Science and Technology Jinchun Xue ( $\nabla 1023817019 @ q q . c o m$ )

School of Energy and Mechanical Engineering, Jiangxi University of Science and Technology

Min $\mathrm{He}$

School of Software Engineering, Jiangxi University of Science and Technology

Jiajia You

School of Energy and Mechanical Engineering, Jiangxi University of Science and Technology

Weiwei Wang

School of Energy and Mechanical Engineering, Jiangxi University of Science and Technology

Huaqin Han

School of Energy and Mechanical Engineering, Jiangxi University of Science and Technology

Li Tan

Emergency Rescue Service Center of Haojiang District

\section{Research Article}

Keywords: copper mine, HDS sediment, phytoremediation, heavy metal

Posted Date: March 3rd, 2022

DOI: https://doi.org/10.21203/rs.3.rs-1357532/v1

License: (9) (i) This work is licensed under a Creative Commons Attribution 4.0 International License.

Read Full License 


\section{Abstract \\ Purpose}

HDS sediment is a type of solid waste produced when the high-concentration mud method (HDS) is adopted to treat acid wastewater from copper mines. It can rationally utilize sediment resources by using phytoremediation.

\section{Methods}

To reveal the effect of different phytoremediation on the heavy metal, enrichment capacity and microbial diversity of the HDS sediments of copper mines, in this experiment, the HDS sediments of a copper mine without phytoremediation were selected as the control group, while the sediments of black locust (Robinia pseudoacacia), slash pine (Pinus elliottii Engelmann) and Chinese white poplar (Populus tomentosa Carr.) were used as test groups to analyze the physical and chemical properties, heavy metal pollution and bioaccumulation capacity of HDS sediments under three phytoremediation.

\section{Results}

The results show that different phytoremediation can reduce the sediment's conductivity and adjust the sediment's $\mathrm{pH}$ value to the range suitable for plant growth. The $\mathrm{BCF}_{\text {Shoot }}$ and BTF values of Chinese white poplar to $\mathrm{Cd}$ and $\mathrm{Zn}$ and slash pine to $\mathrm{Pb}$ were both greater than 1 .

\section{Conclusions}

As discovered from the bioconcentration coefficient and biotransport coefficient results, Chinese white poplar is an enriched plant of $\mathrm{Cd}$ and $\mathrm{Zn}$, while slash pine is a plant full of $\mathrm{Pb}$.

\section{Introduction}

With the rapid development of the world's economy and industrialization, the demand for copper resources has progressively increased ${ }^{[1]}$. At the same time, a large amount of acid wastewater will be generated during the mining of copper mines. In this context, the High-density Sludge (HDS) process is the main effective method used to treat acid mine wastewater and thus improve the recovery rate of mineral resources ${ }^{[2]}$. The HDS process flow is shown in Fig. 1. In the HDS treatment process, many heavy metal elements in the ore will enter the HDS sediment with the wastewater. After their introduction into HDS sediment, heavy metal elements affect the physicochemical properties and microorganisms of HDS sediment directly or indirectly. As the accumulation time of HSD sediment increases, the heavy metal elements in it will gradually transfer to the soil of the dumpsite. Then, the pollution caused by heavy 
metals is a severe risk to the surrounding ecosystem because of its toxicity ${ }^{[3]}$, non-biodegradability, and bioaccumulation ${ }^{[4]}$. Heavy metals in soil may transport and accumulate in the human body along the food chain ${ }^{[5]}$. In this case, heavy metal pollution has become one of the most serious environmental problems in mining areas.

Nowadays, a variety of remediation approaches, including physical remediation (guest land methods, electro-remediation methods and thermal desorption methods), chemical remediation (Add fixative or acid-base leaching agents containing porous structure material, etc.), and biological remediation (microbial remediation and phytoremediation) approaches ${ }^{[6][7]}$ have been developed to reclaim heavy metal-polluted soils. The physical repair method is widely used in engineering, but it is featured with a large amount of engineering, short-time effect, and high cost. The chemical remediation method has a large amount of precipitated sludge and is environmentally damaging. Whereas, phytoremediation adopts the ability of plants to remove the heavy metal of soil ${ }^{[8]}$ which is regarded as the most costeffective and environmentally friendly technique for remediation of heavy metal-contaminated soils ${ }^{[9]}$; besides, it uses plants to extract and transport elemental pollutants in the soil, thus stabilizing the fertility of plant growth substrates ${ }^{[10]}$. Actually, more than 400 plants have been found to have the ability to super-enrich heavy metals ${ }^{[11]}$. For example, the ryegrass possesses a strong cadmium ion enrichment ability, and there are differences between different types of ryegrass ${ }^{[12]}$. B. papyrifera has an excellent enrichment ability for lead, cadmium and zinc ions, and different ions feature different enrichment levels in different parts of the plant ${ }^{[13]}$. Pteris vittata $\mathrm{L}$. is also called "As hyperaccumulator plant" due to its high ability to accumulate arsenic ${ }^{[14]}$. In recent years, applications of phytoremediation technology to the heavy metal pollution of solid waste in mining areas have been rapidly advancing. Solid waste in mining areas includes tailings generated during beneficiation and HDS sediment generated in mine wastewater treatment. Solanum viarum Dunal is used for solving heavy metal problems in tailings ${ }^{[15]}$, and shows potential applicability for the treatment of areas contaminated by heavy metals in the mining area. Quercus spp. and Salix spp. were planted into the tailings containing lead and zinc ions. Due to the different mechanisms operated to confer tolerance of heavy metals, the root systems for heavy metals transhipment showed obvious differences ${ }^{[16]}$. When being planted in mine tailings containing copper, manganese, zinc and lead, even if the concentration of heavy metals in the tailings is different, ryegrass can still treat heavy metals there ${ }^{[17]}$. Clearly, it is found that little research is carried out on the use of phytoremediation techniques to repair HDS sediments contaminated by heavy metals.

As adaptability to the growth environment varies with plants, the growth environment has a great influence on the effect of phytoremediation ${ }^{[18]}$. Therefore, it is the key to phytoremediation technology to find heavy metal-rich plants suitable for growth in contaminated soil[19][20]. Native plant species are generally superior to introduced plants in terms of growth and reproduction under environmental stress ${ }^{[21]}$ ${ }^{[22]}$. The use of native plant species for phytoremediation is of great importance, which is a key element in the efficiency of phytoremediation strategies ${ }^{[23][24]}$. After testing and analysis, the bottom mud contains multiple heavy metals such as $\mathrm{Cu}, \mathrm{Cd}, \mathrm{Zn}, \mathrm{Pb}, \mathrm{Cr}$ and $\mathrm{Hg}$, when four heavy metals namely $\mathrm{Cu}, \mathrm{Cd}, \mathrm{Zn}$, and 
$\mathrm{Pb}$ have the highest content, so that the subsequent tests are all about these four heavy metals. In fact, the heavy metals in the sediment are easy to form and accumulate, which will eventually threaten the ecological environment of the mining area. Considering that, in this experiment, three native plant species, including slash pine (Pinus elliottii Engelmann), Chinese white poplar (Populus tomentosa Carr.) and black locust (Robinia pseudoacacia), grown in the experimental area were used to remediate heavy metals in HDS sediments. Besides, the accumulation and transportation of heavy metals in different plants were analyzed, and its rules were also explored. At the same time, the thermogravimetric analysis on the sediments after different phytoremediation was carried out to identify the changes in the properties of the sediments before and after the improvement, which provides data support for the phytoremediation of heavy metals in the experimental area and similar areas.

\section{Materials And Methods}

\subsection{Study area}

The test area is located in a mining area in southeastern China and covers about $100 \mathrm{~km}^{2}$. The mining area is a typical northwest low mountain and hilly region, featured with the topography of rolling hills in the southeast. It has a subtropical monsoon humid climate with a mean annual temperature of about $16-18^{\circ} \mathrm{C}$, about $70-550 \mathrm{~m}$, and its rainfall is abundant, and the mean annual precipitation is $1970-1990$ $\mathrm{mm}$, where around $70-90 \%$ of the precipitation is in May and June. The HDS sediments of this experiment were taken from the dumpsite of the mining area, the southwest direction of which was the test site with a total area of about $2620 \mathrm{~m}^{2}$.

\subsection{Materials}

Plants selected in this experiment, including black locust (Robinia pseudoacacia), slash pine (Pinus elliottii Engelmann) and Chinese white poplar (Populus tomentosa Carr. ), were obtained commercially from Muyangdou Seed Research Industry Co., LTD and all comply with Chinese phytosanitary regulations.

\subsection{Experimental design and treatments}

According to the climate conditions of the test area and the genetic resources of native plant species, in April 2017, a test area was established. Then, slash pine (Pinus elliottii Engelmann), Chinese white poplar (Populus tomentosa Carr.) and black locust (Robinia pseudoacacia) were planted there. The HDS sediment thickness in the test area was about $80 \mathrm{~cm}$, and about 2000 cubic meters of HDS sediments were used. The species planted and plant root stem and leave samples grown in the experimental area are shown in Fig. 2. The root, stem, leaf and sediment of the above three plants were collected in July 2021. In this experiment, four groups of different treatments were set, when the sediment without planting any plant was employed as the control group (CK), while those planted with slash pine, Chinese white poplar and black locust were the test groups. Besides, these plants in the figures and tables in this study were marked as $1 \#, 2 \#$ and $3 \#$, respectively. Before starting sample collection, the samplers such as 
garden shears and machetes were wiped with alcohol disinfection equipment. Here, it should be noted that this step should be repeated each time when the sample plot was replaced so as to reduce errors. Apart from that, these samples were collected in three randomly selected $2 \mathrm{~m} \times 2 \mathrm{~m}$ quadrats, in each of which three plants have similar growth. Then, gardening shears and machetes were used to obtain plant branches and roots, and collect leaf, stem and root samples, while sediment samples were acquired within the range of $0-25 \mathrm{~cm}$ from the main plant stem. After that, all samples were put into a sealed sample bag and placed in a low-temperature incubator. Furthermore, the quality of all samples in the sealed sample bag was controlled to about $80 \mathrm{~g}$, which was then brought back to the laboratory to determine the heavy metal content.

\subsection{Sediment analysis and statistical analysis}

The sediment and plant samples were put into a drying box and dried at $40^{\circ} \mathrm{C}$ for 48 hours. Then, the dried samples were crushed, thoroughly mixed, screened with a 40-mesh sieve and loaded into a sample vial. After that, heavy metal analysis was performed by weighing $0.2 \mathrm{mg}$ of samples taken in a conical flask, and adding $5 \mathrm{ml}$ nitric acid and $1 \mathrm{~mol}$ perchloric acid, followed by placing it on the Graphite Digestion Instrument at $200^{\circ} \mathrm{C}$ until the solution in the conical flask became colorless. Afterwards, it was poured into a $50 \mathrm{ml}$ volume. The volume was increased to $50 \mathrm{~mL}$ with distilled water. Other than that, the metal content was measured by ICP-MS. As for thermogravimetric analysis experiment, weigh 15-20 mg of samples; place them in an alumina crucible, and then put them into the WCT-122 thermogravimetric analyzer. Nitrogen was used as the protective gas, at a flow rate of $18 \mathrm{~mL} \mathrm{~min}^{-1}$, while the temperature range was from $25^{\circ} \mathrm{C}$ to $1000^{\circ} \mathrm{C}$ with a heating rate of $20^{\circ} \mathrm{C} \mathrm{min}^{-1}$. In order to eliminate experimental errors, a baseline calibration under the same conditions was performed before each sample test. Moreover, the $\mathrm{pH}$ and electrical conductivity of the sediment were determined by the water extraction potential method and the conductivity meter respectively.

The experimental data was processed, analyzed, and graphed by SPSS 22, Origin 8, and Microsoft Excel 2016 software.

The bioconcentration factor $(\mathrm{BCF})^{[25]}$ represents the ability of a certain metal in plant stems and leaves or roots $^{[26][27]}$. The bioconcentration factor of plant aerial parts (stems and leaves) is calculated by formula (1), while that of the plant underground part (plant root) is by formula (2):

$$
\begin{gathered}
B C F_{\text {Shoot }}=\frac{[\text { Metals }]_{\text {Shoot }}}{[\text { Metals }]_{\text {Sediment }}} \\
B C F_{\text {Root }}=\frac{[\text { Metals }]_{\text {Root }}}{[\text { Metals }]_{\text {Sediment }}}
\end{gathered}
$$

where $[\text { Metals }]_{\text {Shoot }}$ represents the total concentration of heavy metals in plant stems and leaves; $[\text { Metals }]_{\text {Root }}$ refers to the total concentration of heavy metals in the roots of the plant, and $[\mathrm{Metals}]_{\text {Sediment }}$ 
indicates the concentration of heavy metals in the bottom silt of plants.

The biological transport factor $(\mathrm{BTF})^{[28]}$ reflects the ability of plants to transport heavy metals, and is the ratio of the concentration of heavy metals in the above-ground and underground parts of the plant ${ }^{[29][30]}$. The biological transport coefficient is calculated by formula (3):

$$
\text { BTF }=\frac{[\text { Metals }]_{\text {Shoot }}}{[\text { Metals }]_{\text {Root }}}
$$

where $[\text { Metals }]_{\text {Shoot }}$ represents the total concentration of heavy metals in plant stems and leaves, while $[\text { Metals }]_{\text {Root }}$ means the total concentration of heavy metals in the roots of the plant.

\section{Results}

\subsection{Phytoremediation effects of different plants on the $\mathrm{pH}$ value and conductivity of HDS sediment}

The $\mathrm{pH}$ of the plant growth substrate will directly affect its biochemical characteristics, thereby affecting plant growth. As shown in Fig. 3, the pH of the control group was 7.97, which was alkaline. After three kinds of phytoremediation, the $\mathrm{pH}$ value of the sediment decreased slightly. Among them, the $\mathrm{pH}$ of the sediment of the black locust group decreased most significantly, reaching 7.71, while the effect of other test groups on improving the $\mathrm{pH}$ value of sediment was: slash pine (7.81) > Chinese white poplar (7.86).

The conductivity of the sediment is a parameter of sediment salinity, which can indicate the salt content in the sediment and is an important factor that highlights the presence of nutrients in the soil. As shown in Fig. 2, after phytoremediation, the HDS sediment content showed a certain upward trend. The conductivity of the control group, the black locust group, the slash pine group and the Chinese white poplar was $213 \mathrm{~ms} \mathrm{~s}^{-1}, 241 \mathrm{~ms} \mathrm{~s}^{-1}, 226 \mathrm{~ms} \mathrm{~s}^{-1}$, and $235 \mathrm{~ms} \mathrm{~s}^{-1}$, respectively, when there was an increase of $13.1 \%, 6.1 \%$, and $10.3 \%$ accordingly, compared with the control group.

\subsection{Thermogravimetric analysis of sediment after different phytoremediation}

Thermogravimetric (TG) profiles of selected samples together with the derivative thermogravimetric (DTG) curves are displayed in Fig. 4 and Fig. 5. Through the TG and DTG curves, each group of sediments at different stages of thermal weight loss, the maximum thermal weight loss rate and the corresponding peak temperature can be obtained. Table 1 shows the temperature range, quality change and peak temperature of each group of sediments at different stages of thermal weight loss. With the continuous increase of pyrolysis temperature, the sediments of the control group, the black locust group and the Chinese white poplar group mainly experienced four thermal weight loss stages, while the slash pine group was more complicated and featured with five thermal weight loss processes. The initial 
thermal weight loss of the four groups of samples occurred between $25^{\circ} \mathrm{C}$ and $136^{\circ} \mathrm{C}$. In this stage, the peak temperature of the black locust group was $118.6^{\circ} \mathrm{C}$, followed by the Chinese white poplar group, the slash pine group, and the control group with the peak temperature of $116.0^{\circ} \mathrm{C}, 109.7^{\circ} \mathrm{C}$, and $109.2^{\circ} \mathrm{C}$ in sequence. At this stage, the quality loss of the control group, the black locust group, the slash pine group, and the Chinese white poplar group was $22.3 \%, 26.8 \%, 25.6 \%$, and $26.8 \%$, separately. The second-stage thermal weight loss process of the four groups of samples appeared between $128^{\circ} \mathrm{C}$ and $259^{\circ} \mathrm{C}$. In this stage, the black locust group had the highest quality loss rate of $6 \%$, followed by the Chinese white poplar group, the slash pine group, and the control group, with that of $4.4 \%, 3.7 \%$, and $3.7 \%$ accordingly. The third-stage thermal weight loss process of the control group, the locust group and the Chinese white poplar group existed between $259^{\circ} \mathrm{C}-791^{\circ} \mathrm{C}$. Within a similar temperature range, the Chinese white poplar group showed two thermal weight loss stages (stage III and IV), and the mass-loss rates were $1.5 \%$ and $11.4 \%$, respectively, which was lower than that of the black locust group and higher than that of the control and slash pine groups. Furthermore, the quality loss rates of the control group, the black locust, the slash pine group, and the Chinese white poplar group in the last thermal weight-loss stage were $2.5 \%$, $3.4 \%, 3.5 \%$, and $3.4 \%$, respectively. After the four groups of sediments were pyrolyzed at $25-1000^{\circ} \mathrm{C}$, the unburned residues of the original sediments were the most, reaching $62.6 \%$, followed by the slash pine group, the black locust group, and the Chinese white poplar group with that of $58 \%, 54.1 \%$, and $52 \%$ in order. 
Table 1

The temperature range, quality change and peak temperature of the sediment after phytoremediation at different stages of thermal weight loss. CK, the sediment without phytoremediation; T1, planted black locust; T2, planted slash pine; T3, planted Chinese white poplar.

\begin{tabular}{|c|c|c|c|c|}
\hline Sample & $\begin{array}{l}\text { Weight loss } \\
\text { stages }\end{array}$ & $\begin{array}{l}\text { Temperature ranges } \\
\left({ }^{\circ} \mathrm{C}\right)\end{array}$ & $\begin{array}{l}\text { Quality change rate } \\
\text { (\%) }\end{array}$ & $\begin{array}{l}\text { Peak temperatures } \\
\left({ }^{\circ} \mathrm{C}\right)\end{array}$ \\
\hline \multirow[t]{4}{*}{ CK } & प & $25.0-134.8$ & 22.3 & 109.2 \\
\hline & प & $134.8-249.6$ & 3.7 & 167.5 \\
\hline & ૫ & $249.6-756.3$ & 8.9 & 279.1 \\
\hline & प & $756.3-1000.0$ & 2.5 & 815.8 \\
\hline \multirow[t]{4}{*}{ T1 } & $\square$ & $25.0-135.4$ & 26.8 & 118.6 \\
\hline & ૫ & $135.4-258.1$ & 6.0 & 195.8 \\
\hline & $\square$ & $258.1-790.1$ & 15.7 & 667.1 \\
\hline & प & $790.1-1000.0$ & 3.4 & 854.4 \\
\hline \multirow[t]{5}{*}{ T2 } & $\square$ & $25.0-128.7$ & 25.6 & 109.7 \\
\hline & ૫ & $128.7-241.4$ & 4.4 & 171.3 \\
\hline & ૫ & $241.4-437.7$ & 1.5 & 415.6 \\
\hline & प & $437.7-767.8$ & 11.4 & 457.6 \\
\hline & प & $767.8-1000.0$ & 3.5 & 807.1 \\
\hline \multirow[t]{4}{*}{ T3 } & ? & $25.0-133.5$ & 26.8 & 116.0 \\
\hline & ૫ & $133.5-246.2$ & 3.7 & 193.8 \\
\hline & ૫ & $246.2-770.9$ & 12.1 & 604.9 \\
\hline & Q & $770.9-1000.0$ & 3.4 & 839.1 \\
\hline
\end{tabular}

\subsection{Plant heavy metal content under different phytoremediation}

The contents of heavy metals in the sediments and plants of each group are shown in Table 2. The Cd, $\mathrm{Cu}, \mathrm{Zn}$, and $\mathrm{Pb}$ contents of the sediment after planting black locust were $1.47 \mathrm{mgkg}^{-1}, 414.27 \mathrm{mg} \mathrm{kg}^{-1}$, $272.09 \mathrm{mg} \mathrm{kg}^{-1}$, and $15.55 \mathrm{mg} \mathrm{kg}^{-1}$, respectively, while the contents of four heavy metals in the sediment after planting slash pine were $0.90 \mathrm{mg} \mathrm{kg}^{-1}, 561.69 \mathrm{mg} \mathrm{kg}^{-1}, 237.59 \mathrm{mg} \mathrm{kg}^{-1}$, and $10.66 \mathrm{mg} \mathrm{kg}^{-1}$, respectively. After planting Chinese white poplar, the contents of heavy metals in the sediments were 1.18 $\mathrm{mg} \mathrm{kg}{ }^{-1}, 594.20 \mathrm{mg} \mathrm{kg}^{-1}, 251.84 \mathrm{mg} \mathrm{kg}^{-1}$, and $13.15 \mathrm{mg} \mathrm{kg}^{-1}$, accordingly. In addition, the heavy metal content of the aerial parts of plants is equal to the addition of the heavy metal content of plant leaves and stems. As for the Cd content in the aerial parts of the three plants, it was Chinese white poplar (2.93 
$\left.\mathrm{mg} \mathrm{kg}{ }^{-1}\right)>$ slash pine $\left(0.92 \mathrm{mg} \mathrm{kg}^{-1}\right)>$ black locust $\left(0.57 \mathrm{mg} \mathrm{kg}^{-1}\right)$, while the Cu content was the black locust $\left(233.65 \mathrm{mg} \mathrm{kg}^{-1}\right)>$ slash pine $\left(82.16 \mathrm{mg} \mathrm{kg}^{-1}\right)>$ Chinese white poplar $\left(44.16 \mathrm{mg} \mathrm{kg}^{-1}\right)$; the $\mathrm{Zn}$ content was Chinese white poplar $\left(553.74 \mathrm{mg} \mathrm{kg}^{-1}\right)>$ slash pine $\left(84.99 \mathrm{mg} \mathrm{kg}^{-1}\right)>$ black locust $(57.69 \mathrm{mg}$ $\left.\mathrm{kg}^{-1}\right)$; and the $\mathrm{Pb}$ content was slash pine $\left(17.59 \mathrm{mg} \mathrm{kg}^{-1}\right)>$ black locust $\left(11.45 \mathrm{mg} \mathrm{kg}^{-1}\right)>$ Chinese white poplar $\left(8.67 \mathrm{mg} \mathrm{kg}^{-1}\right)$. Different from that, the Cd content in the roots of the black locust, slash pine, and the Chinese white poplar was $0.67 \mathrm{mg} \mathrm{kg}^{-1}, 0.27 \mathrm{mg} \mathrm{kg}^{-1}$, and $0.69 \mathrm{mg} \mathrm{kg}^{-1}$; the Cu content was 148.78 $\mathrm{mg} \mathrm{kg}^{-1}, 39.53 \mathrm{mg} \mathrm{kg}^{-1}$, and $86.12 \mathrm{mg} \mathrm{kg}^{-1}$, and the $\mathrm{Zn}$ content was $86.44 \mathrm{mg} \mathrm{kg}^{-1}, 27.86 \mathrm{mg} \mathrm{kg}^{-1}$, and $93.89 \mathrm{mg} \mathrm{kg}^{-1}$, separately, while $\mathrm{Pb}$ content was $4.99 \mathrm{mg} \mathrm{kg}^{-1}, 0.99 \mathrm{mg} \mathrm{kg}^{-1}$, and $1.88 \mathrm{mg} \mathrm{kg}^{-1}$, respectively. The data results show that the black locust has the strongest absorption capacity for $\mathrm{Cu}$ among the three plants, and the absorption of $\mathrm{Zn}$ by the Chinese white poplar group is more than 20 times that of other plants.

Table 2

The contents of heavy metals in the sediments and plants. Values are means \pm standard error. According to Duncan's multiple range test, the data followed by a different letter are significantly different $(P \leq 0.05)$. CK, the sediment without phytoremediation; $T 1$, planted black locust; T2, planted slash pine; T3, planted Chinese white poplar.

\begin{tabular}{|c|c|c|c|c|c|}
\hline \multicolumn{2}{|c|}{ Sample } & \multicolumn{4}{|c|}{ Heavy content $\left(\mathrm{mg} \mathrm{kg}^{-1}\right)$} \\
\hline & & $\mathrm{Cd}$ & $\mathrm{Cu}$ & $\mathrm{Zn}$ & $\mathrm{Pb}$ \\
\hline \multirow[t]{4}{*}{ T1 } & Sediment & $1.47 \pm 0.34$ & $414.27 \pm 87.69$ & $272.09 \pm 9.19$ & $15.55 \pm 0.50$ \\
\hline & leaves & $0.17 \pm 0.06$ & $37.96 \pm 3.05$ & $27.58 \pm 6.81$ & $2.09 \pm 0.61$ \\
\hline & rhizome & $0.4 \pm 0.15$ & $195.69 \pm 297.55$ & $30.11 \pm 3.31$ & $4.37 \pm 1.99$ \\
\hline & root & $0.67 \pm 0.24$ & $148.78 \pm 33.05$ & $86.44 \pm 22.28$ & $4.99 \pm 1.65$ \\
\hline \multirow[t]{4}{*}{ T2 } & Sediment & $0.99 \pm 0.15$ & $561.69 \pm 131.92$ & $237.59 \pm 21.46$ & $10.66 \pm 2.96$ \\
\hline & leaves & $0.2 \pm 0.05$ & $19.87 \pm 3.61$ & $41.66 \pm 10.21$ & $3.99 \pm 1.98$ \\
\hline & rhizome & $0.72 \pm 0.15$ & $62.29 \pm 21.38$ & $43.32 \pm 26.72$ & $12.62 \pm 6.88$ \\
\hline & root & $0.27 \pm 0.14$ & $39.53 \pm 11.65$ & $27.86 \pm 10.34$ & $0.99 \pm 0.58$ \\
\hline \multirow[t]{4}{*}{ T3 } & Sediment & $1.18 \pm 0.04$ & $594.2 \pm 80.13$ & $251.84 \pm 18.80$ & $13.15 \pm 1.82$ \\
\hline & leaves & $1.87 \pm 0.30$ & $20.35 \pm 5.38$ & $420.22 \pm 132.12$ & $4.25 \pm 0.92$ \\
\hline & rhizome & $1.06 \pm 0.12$ & $23.81 \pm 13.71$ & $133.53 \pm 6.99$ & $2.53 \pm 0.50$ \\
\hline & root & $0.69 \pm 0.09$ & $86.12 \pm 44.12$ & $93.89 \pm 18.02$ & $1.88 \pm 0.84$ \\
\hline
\end{tabular}

\subsection{Heavy metal enrichment and transport characteristics under different phytoremediation}


The bioconcentration factor (BCF) and bio-transport factor (BTF) can evaluate the plant's ability to enrich and extract heavy metals from the plant substrate. From Table 2 and formulas (1), (2) and (3), the aboveground bioconcentration coefficient $\left(\mathrm{BCF}_{\text {Shoot }}\right)$, the underground bioconcentration coefficient $\left(\mathrm{BCF}_{\mathrm{Root}}\right)$, and the transport coefficient (BTF) of the four heavy metals in each plant can be calculated. The calculation results are shown in Table 3, from which, it can be seen that the $\mathrm{BCF}_{\text {Shoot }}$ values of Chinese white poplar to $\mathrm{Cd}$ and $\mathrm{Zn}$ and slash pine to $\mathrm{Pb}$ are all greater than 1; the BTF value of the black locust to $\mathrm{Cu}$ and $\mathrm{Pb}$ is greater than 1 ; the $\mathrm{BTF}$ values of slash pine to $\mathrm{Cd}, \mathrm{Cu}, \mathrm{Pb}$ and $\mathrm{Zn}$ are all greater than 1 , and the $B T F$ value of slash pine to $\mathrm{Pb}$ is as high as 16.75 ; besides, the BTF values of Chinese white poplar to $\mathrm{Zn}, \mathrm{Cd}$ and $\mathrm{Pb}$ were greater than 1, being 5.895, 4.244 and 3.608 , respectively. Furthermore, the BTF values of the three plants to $\mathrm{Cd}$ were the Chinese white poplar group (4.244) > Slash pine group (3.403) > black locust group (0.311), to Cu being slash pine group (2.086) > black locust group $(1.571)>$ Chinese white poplar group (0.510), to Zn being the Chinese white poplar group (5.895) > Slash pine group (3.060) > black locust group (0.670), and to $\mathrm{Pb}$ being the Slash pine group (16.750) $>$ Chinese white poplar group (3.608) > black locust group (1.293).

Table 3

Bioconcentration coefficient and transport coefficient of various heavy metals in different plants. CK, the sediment without phytoremediation; T1, planted black locust; T2, planted slash pine; T3, planted Chinese white poplar. $\mathrm{BCF}_{\text {Shoot }}$ represents the total concentration of

heavy metals in plant stems and leaves. $\mathrm{BCF}_{\text {Root }}$ represents the total concentration of heavy metals in the roots of the plant. BTF is the ratio of the concentration of heavy metals in the above-ground and underground parts of the plant.

\begin{tabular}{|clllll|}
\hline \multicolumn{2}{|l}{ Sample } & Cd & Cu & Zn & Pb \\
\hline T1 & BCF $_{\text {Shoot }}$ & 0.143 & 0.564 & 0.213 & 0.415 \\
\cline { 2 - 6 } & BCF $_{\text {Root }}$ & 0.456 & 0.359 & 0.318 & 0.321 \\
\hline & BTF & 0.311 & 1.571 & 0.670 & 1.293 \\
\hline T2 & BCF $_{\text {Shoot }}$ & 0.929 & 0.146 & 0.358 & 1.558 \\
& BCF $_{\text {Root }}$ & 0.273 & 0.070 & 0.117 & 0.093 \\
& BTF $_{13}$ & 3.403 & 2.086 & 3.060 & 16.750 \\
\hline & BCF $_{\text {Shoot }}$ & 2.483 & 0.074 & 2.199 & 0.516 \\
\hline & BCF $_{\text {Root }}$ & 0.585 & 0.145 & 0.373 & 0.143 \\
\hline & BTF & 4.244 & 0.510 & 5.895 & 3.608 \\
\hline
\end{tabular}

\section{Discussion}


As the HDS process is followed to treat acid mine wastewater, a certain amount of alkaline substances such as lime and calcium hydroxide will be used to recover $\mathrm{Cu}^{2+}$ in the mine acid wastewater, which also makes the HDS sediment alkaline ${ }^{[31]}$. After different phytoremediation, the $\mathrm{pH}$ of HDS bottom mud decreased slightly, maybe because the bottom mud is the product of acid wastewater treatment in the mining area, and it contains a lot of heavy metals, such as $\mathrm{Cu}, \mathrm{Zn}, \mathrm{Cd}$ and $\mathrm{Pb}^{[32]}$. When adopting phytoremediation technology to repair HDS sediment, each plant has a certain transport effect on the heavy metals in the sediment ${ }^{[33][34]}$. When the content of heavy metals in the sediment decreases, the $\mathrm{pH}$ value of the sediment will show a certain downward trend. Besides, by comparing the $\mathrm{pH}$ measurement results a year ago ${ }^{[35]}$, it can be found that the $\mathrm{pH}$ value of the sediment without planting any plant ranges from 7.5 to 9.5. Regardless of whether phytoremediation increases or decreases the $\mathrm{pH}$ of the sediment, phytoremediation can always adjust the $\mathrm{pH}$ of the plant growth substrate to a range suitable for plant growth.

The conductivity of the sediment is an indicator of salinization degree of the sediment ${ }^{[36][37]}$. The increase in electrical conductivity of each group after phytoremediation may be because the water content of the sediment before remediation is much higher than that of the test group ${ }^{[38]}$. The decrease in water content of each group after phytoremediation affects the salinity of the sediment, which leads to the increase of the conductivity of each group after phytoremediation. As is known to all, water exists in clay in four forms: adsorbed water, interlayer water, crystal water and structured water ${ }^{[39]}$, and their dehydration temperature is $0-100^{\circ} \mathrm{C}, 100-250^{\circ} \mathrm{C}, 200-500^{\circ} \mathrm{C}$, and $600-1000^{\circ} \mathrm{C}$ accordingly ${ }^{[40]}$. The evaporation of adsorbed water mainly causes the initial thermal weight loss of the four groups of sediments in the sample ${ }^{[41]}$. The peak temperature of the black locust group is the highest at this stage, which indicates that the water retention performance of the bottom mud after restoration by the black locust is the best ${ }^{[42]}$. In addition, the peak temperature of the bottom sludge after phytoremediation is higher than that of the original bottom sludge at this stage, which reveals that the water retention capacity of the bottom sludge after phytoremediation has been improved to a certain extent. Other than that, volatile organic compounds play a key role in plant growth. Biological volatile organic compounds are derived from the release of soil bacteria, fungi and other rhizosphere microorganisms in plant-derived and plant growth substrates ${ }^{[43]}$, a compound with a low melting point. The second stage thermal weight loss of the four groups of sediments may be caused by the volatilization and thermal decomposition of volatile organic compounds in the sediments ${ }^{[44]}$. In the second stage of thermal weight loss, the black locust group had the highest total mass loss rate, showing that the bottom sludge planted with black locust contained the highest content of low boiling point compounds non-biopolymer components ${ }^{[45]}$, followed by the Chinese white poplar group, the slash pine group and the control group. Unlike the second stage, the third stage of weight loss in the control group, the black locust group, and the Chinese white poplar group may be due to the decomposition and volatilization of organic matter and stored organic carbon in the bottom mud after heating ${ }^{[46]}$. Here, it should be mentioned that the third and fourth stages of slash pine may be for the same reason. At this stage, the mass-loss rates of the three sediments after phytoremediation are higher than those of the control group, meaning that the organic matter and fixed 
carbon content of the sediments after phytoremediation have increased partly ${ }^{[47]}$, which is in accordance with previous findings ${ }^{[48]}$. The final stage of the thermal weight loss of the four groups of bottom sludge may result from the further combustion of residual coke products produced during the previous pyrolysis process ${ }^{[49]}$. After the pyrolysis process, the unpyrolyzed residue of the original bottom mud is the largest, displaying that the original sediment contains higher mineral elements, and also verifying to a certain extent that phytoremediation has a transport effect on the mineral elements in the sediment ${ }^{[50]}$.

Planting plants into heavy metal-contaminated plant growth substrates can be classified into enrichment plants, root hoarding plants and avoidance plants according to the characteristics of plants $\mathrm{BCF}_{\text {Shoot }}$ $\mathrm{BCF}_{\text {Root, }}$ and $\mathrm{BTF}^{[51]}$. When the $\mathrm{BCF}_{\text {Shoot }}$ value and $\mathrm{BTF}$ value of a plant are greater than 1 , the plant is considered an enriched plant ${ }^{[52]}$. When the $\mathrm{BCF}_{\text {Root }}$ value is greater than 1 , and the $\mathrm{BTF}$ value is less than 1 , the plant is considered a root hoarding plant ${ }^{[53]}$. When the $\mathrm{BCF}_{\text {Shoot }}$ value and the $\mathrm{BCF}_{\mathrm{Root}}$ value are less than 1 , the plant belongs to the evasive plant ${ }^{[54]}$. From Table 3 , the $\mathrm{BCF}_{\text {Shoot }}$ value and BTF value of the Chinese white poplar for $\mathrm{Cd}$ and $\mathrm{Zn}$ are greater than 1 , so the Chinese white poplar is an enriched plant of $\mathrm{Cd}$ and $\mathrm{Zn}$. The $\mathrm{BCF}_{\text {Shoot }}$ of the slash pine to $\mathrm{Pb}>1$ and $\mathrm{BTF}>1$, so slash pine is a $\mathrm{Pb}$-rich plant.

\section{Conclusions}

Phytoremediation is considered to be one of the friendliest methods of treating heavy metal pollutants. In summary, the results of this study show that phytoremediation can adjust the $\mathrm{pH}$ value of the plant growth substrate to a range suitable for plant growth, and it can also enhance the electrical conductivity of the plant growth substrate to a certain extent. In the treatment of heavy metals, phytoremediation has also shown a positive enrichment effect. Chinese white poplar is an enriched plant of $\mathrm{Cd}$ and $\mathrm{Zn}$, and slash pine is an enriched plant of $\mathrm{Pb}$. With the development of mineral resources, the problem of heavy metal pollution from mine waste will become increasingly serious, which will severely threaten the safety of global people and the development of the world economy. Considering that, this experimental method can solve the above problems from an environmentally friendly perspective and reduce the impact of heavy metals in mine waste.

\section{Declarations}

\section{Acknowledgments}

This work was supported by the Key R\&D projects in Jiangxi Province, China (20212BBG73013).

\section{Funding}

This work was funded by the Key R\&D projects in Jiangxi Province, China (20212BBG73013).

\section{Conflicts of interest/Competing interests}


We declare that we do not have any commercial or associative interest that represents a conflict of interest in connection with the work submitted.

\section{Availability of data and material}

All data included in this study are available upon request by contact with the corrosponding author.

\section{Code availability}

Not applicable.

\section{Authors' contributions}

Ruoyan Cai performed the data analyses and wrote the manuscript; Jinchun Xue and Min He contributed to the conception of the study; Jiajia You and Weiwei Wang contributed significantly to the analysis;

Huaqin Han performed the experiment;

Li Tan helped perform the analysis with constructive discussions.

\section{Ethics approval}

Not applicable' for that section

\section{Consent to participate}

Not applicable' for that section

\section{Consent for publication}

Not applicable' for that section

\section{References}

1. Buayam N, Davey MP, Smith AG, Pumas C (2019). Effects of copper and pH on the growth and physiology of Desmodesmus sp. AARLG074. Metabolites, 9:84. https://doi.org/10.3390/metabo9050084

2. Mackie AL, Walsh ME (2015). Investigation into the use of cement kiln dust in high density sludge (HDS) treatment of acid mine water. Water Res, 85: 443-450. https://doi.org/10.1016/j.watres.2015.08.056

3. Pan LH, Wang ZQ, Yang Q, Huang RY (2018). Efficient removal of lead, copper and cadmium ions from water by a porous calcium alginate/graphene oxide composite serogel. Nanomaterials-basel, 
8:957. https://doi.org/10.3390/nano8110957

4. Shehata EA, Liu YW, Feng Y, Cheng D, Li Z (2019). Changes in Arsenic and Copper Bioavailability and Oxytetracycline Degradation during the Composting Process. Molecules, 24: 4240. https://doi.org/10.3390/molecules24234240

5. Ma J, Quan Z, Sun Y, Du J, Liu B (2020). Excess sulfur and Fe elements drive changes in soil and vegetation at abandoned coal gangues, Guizhou China. Sci Rep-UK, 10. https://doi.org/10.1038/s41598-020-67311-z

6. Cheng S, Chen T, Xu WB, Huang J, Yan B (2020). Application research of biochar for the remediation of soil heavy metals contamination: a weview. Molecules, 25:3167. https://doi.org/10.3390/molecules25143167

7. Mcgrath SP, Chang AC, Page AL, Witter E (1994). Land application of sewage sludge: scientific perspectives of heavy metal loading limits in Europe and the United States. Environ Rev, 2: 108-118. https://doi.org/10.1139/a94-006

8. Fu Y, Mason AS, Zhang Y, Lin B, Yu H (2019). MicroRNA-mRNA expression profiles and their potential role in cadmium stress response in Brassica napus. BMC Plant Biol, 19. https://doi.org/10.1186/s12870-019-2189-9

9. Zhao JM, Xia B, Meng Y, Yang ZF, Zhang XQ (2019). Transcriptome Analysis to Shed Light on the Molecular Mechanisms of Early Responses to Cadmium in Roots and Leaves of King Grass (Pennisetum americanum × P. purpureum). Int J of Mol Sci, 20: 2532. https://doi.org/10.3390/ijms20102532

10. Jacob JM, Karthik C, Saratale RG, Kumar SS, Prabakar D, Kadirvelu K, Pugazhendhi A (2018). Biological approaches to tackle heavy metal pollution: A survey of literature. Journal Environ Manage, 217: 56-70. https://doi.org/10.1016/j.jenvman.2018.03.077

11. Baker AJM, Mcgrath SP, Sidoli C, Reeves RD (1994). In situ remediation of metal-contaminated soils using crops of hyperaccumulator plants: potentials and future prospects.

12. Li Y, Qin Y, Xu W, Chai Y, Feng D (2019). Differences of Cd uptake and expression of $M T$ family genes and NRAMP2 in two varieties of ryegrasses. Environ Sci Pollut R, 26: 13738-13745. https://doi.org/10.1007/s11356-018-2649-z

13. Zhao XL, Liu JF, Xia XL, Chu JM, Yuan W, Shi SQ, Chang EM, Yin WL, Jiang ZP (2014). The evaluation of heavy metal accumulation and application of a comprehensive bio-concentration index for woody species on contaminated sites in Hunan, China. Environ Sci Pollut R, 21: 5076-5085. https://doi.org/10.1007/s11356-013-2393-3

14. Chen T, Lei M, Wan X, Yang J, Zhou X (2018). Arsenic hyperaccumulator Pteris vittata L. and its application to the field. Twenty Years Res Dev on Soil Pollut Remediation in China. Springer Singapore, Singapore, pp. 465-476.

15. Afonso TF, Demarco CF, Pieniz S, Camargo F, Andreazza R (2019). Potential of Solanum viarum Dunal in use for phytoremediation of heavy metals to mining areas, southern Brazil. Environ Sci Pollut R, 26: 24132-24142. https://doi.org/10.1007/s11356-019-05460-z 
16. Shi X, Wang SF, Sun HJ, Chen YT, Wang DX, Pan HW, Zou YZ, Liu JF, Zheng LY, Zhao XL (2017). Comparative of Quercus spp. and Salix spp. for phytoremediation of Pb/Zn mine tailings. Environ Sci Pollut Res, 24:3400-3411. https://doi.org/10.1007/s11356-016-7979-0

17. Mugica-Alvarez V, Cortés-Jiménez V, Vaca-Mier M, Domínguez-Soria V (2015). Phytoremediation of Mine Tailings Using Lolium Multiflorum. Int J Environ Sci Dev, 6: 246-251. https://doi.org/10.7763/IJESD.2015.V6.599

18. Pérez R, Tapia Y, Antilén M, Casanova M, Cornejo P (2021). Rhizosphere management for phytoremediation of copper mine tailings. J Soil Sci Plant Nut. https://doi.org/10.7763/IJESD.2015.V6.599

19. Ali H, Khan E, Sajad MA (2013). Phytoremediation of heavy metals: concepts and applications. Chemosphere, 91: 869-881. https://doi.org/10.1016/j.chemosphere.2013.01.075

20. Saxena G, Purchase D, Mulla SI, Saratale GD, Bharagava RN (2019). Phytoremediation of heavy metal-contaminated sites: eco-environmental concerns, field studies, sustainability issues and future prospects. Rev Environ Contam T, 249: 71-131. https://doi.org/.10.1007/398_2019_24

21. Cuevas JG, Quiroz M (2019). Screening of native and exotic tree species in Chile for element absorption from dairy slurry. J Soil Sci Plant Nut. https://doi.org/10.1007/s42729-018-0002-8

22. Kumari A, Lal B, Rai UN (2015). Assessment of native plant species for phytoremediation of heavy metals growing in the vicinity of NTPC sites, Kahalgaon, India. Int J Phytoremediat, 18: 592-597. https://doi.org/10.1080/15226514.2015.1086301

23. Fernández S, Poschenrieder C, Marcenò C, Gallego JR, Jiménez-Gámez D, Bueno A, Afif E (2017). Phytoremediation capability of native plant species living on $\mathrm{Pb}-\mathrm{Zn}$ and $\mathrm{Hg}$-As mining wastes in the Cantabrian range, north of Spain. J Geochem Explor, 174: 10-20. https://doi.org/10.1016/j.gexplo.2016.05.015

24. Marrugo-Negrete J, Marrugo-Madrid S, Pinedo-Hernandez J, Durango-Hernandez J, Diez S (2016). Screening of native plant species for phytoremediation potential at a Hg-contaminated mining site. Sci Total Environ, 542: 809-816. https://doi.org/10.1016/j.scitotenv.2015.10.117

25. Souza S, Andrade S, Souza L, Schiavinato MA (2012). Lead tolerance and phytoremediation potential of Brazilian leguminous tree species at the seedling stage. J Environ Manage, 110: 299307. https://doi.org/10.1016/j.jenvman.2012.06.015

26. Mellem JJ, Baijnath $\mathrm{H}$, Odhav B (2009). Translocation and accumulation of $\mathrm{Cr}, \mathrm{Hg}, \mathrm{As}, \mathrm{Pb}, \mathrm{Cu}$ and $\mathrm{Ni}$ by Amaranthus dubius (Amaranthaceae) from contaminated sites. J Environ Sci Heal A, 44: 568575. https://doi.org/10.1080/10934520902784583

27. Zacchini M, Pietrini F, Mugnozza GS, lori V, Pietrosanti L, Massacci A (2009). Metal Tolerance, Accumulation and Translocation in Poplar and Willow Clones Treated with Cadmium in Hydroponics. Water Air Soil Poll, 197: 23-34. https://doi.org/10.1007/s11270-008-9788-7

28. Mellem JJ, Baijnath $\mathrm{H}$, Odhav B (2012). Bioaccumulation of $\mathrm{Cr}, \mathrm{Hg}, \mathrm{As}, \mathrm{Pb}$, Cu and Ni with the ability for hyperaccumulation by Amaranthus dubius. Afr J Agr Res, 7: 591-596. https://doi.org/10.5897/AJAR11.1486 
29. Hammad DM (2011). Cu, Ni and Zn phytoremediation and translocation by water hyacinth plant at different aquatic environments. Aust J Basic Applied Sci, 5: 11-22.

30. Yoon J, Cao XD, Zhou QX, Ma LQ (2006). Accumulation of Pb, Cu, and Zn in native plants growing on a contaminated Florida site. Sci Total Environ, 368: 456-464.

https://doi.org/10.1016/j.scitotenv.2006.01.016

31. Kalin M, Fyson A, Wheeler WN (2006). The chemistry of conventional and alternative treatment systems for the neutralization of acid mine drainage. Sci Total Environ, 366: 395-408. https://doi.org/10.1016/j.scitotenv.2005.11.015

32. Tangahu BV, Sheikh Abdullah SR, Basri H, Idris M, Anuar N, Mukhlisin M (2011). A review on heavy metals $(\mathrm{As}, \mathrm{Pb}$, and $\mathrm{Hg}$ ) uptake by plants through phytoremediation. Int $\mathrm{J}$ Chem Eng, 2011: 1-31. https://doi.org/10.1155/2011/939161

33. Emenike CU, Barasarathi J, Pariatamby A, Hamid FS (2018). Biotransformation and removal of heavy metals: a review of phyto and microbial remediation assessment on contaminated soil. Environ Rev, 26. https://doi.org/10.1139/er-2017-0045

34. Ruqaya, Jabeen, Altaf, Ahmad, Muhammad, lqbal (2009). Phytoremediation of Heavy Metals: Physiological and Molecular Mechanisms. Bot. Rev, 75:339-364. https://doi.org/10.1007/s12229009-9036-x

35. Cai RY, Xue JC, Tan L, Zhao ZY, Zhang ZY (2021). Study on physicochemical properties of Highdensity sludge sediment in copper mine after phytoremediation. J Soil Sci Plant Nut. https://doi.org/10.1007/s42729-021-00575-0

36. Afonso S, Arrobas M, Rodrigues MN (2020). Soil and plant analyses to diagnose hop fields irregular growth. J Soil Sci Plant Nut, 20: 1999-2013. https://doi.org/10.1007/s42729-020-00270-6

37. Pan C, Liu C, Zhao H, Wang Y (2013). Changes of soil physico-chemical properties and enzyme activities in relation to grassland salinization. Eur J Soil Biol, 55: 13-19. https://doi.org/10.1016/j.ejsobi.2012.09.009

38. Jampasri K, Pokethitiyook P, Poolpak T, Kruatrachue M, Kumsopa A (2019). Bacteria-assisted phytoremediation of fuel oil and lead co-contaminated soil in the salt-stressed condition by chromolaena odorata and Micrococcus luteus. Int J Phytoremediat, 22: 1-12. https://doi.org/10.1080/15226514.2019.1663482

39. Cases JM (1997). Mechanism of adsorption and desorption of water vapor by homoionic montmorillonite: 3. the $\mathrm{Mg}^{2+}, \mathrm{Ca}^{2+}, \mathrm{Sr}^{2+}$ and $\mathrm{Ba}^{2+}$ exchanged forms. Clay Clay Miner, 45: 8-22. https://doi.org/10.1346/CCMN.1997.0450102

40. Schuttlefield JD, Cox D, Grassian VH (2007). An investigation of water uptake on clays minerals using ATR-FTIR spectroscopy coupled with quartz crystal microbalance measurements. J Geophys Res-Atmos, 112. https://doi.org/10.1029/2007JD008973

41. Tang $P$, Zhao $Y$, Xia $F(2008)$. Thermal behaviors and heavy metal vaporization of phosphatized tannery sludge in incineration process. J Environ Sci, 20: 1146-1152. https://doi.org/10.1016/S1001-0742(08)62162-2 
42. Opatokun SA, Yousef LF, Strezov V (2017). Agronomic assessment of pyrolysed food waste digestate for sandy soil management. J Environ Manage, 187: 24-30. https://doi.org/10.1016/j.jenvman.2016.11.030

43. Naznin HA, Kimura M, Miyazawa M, Hyakumachi M (2013). Analysis of volatile organic compounds emitted by plant growth-promoting fungus Phoma $s p$. GS8-3 for growth promotion effects on tobacco. Microbes Environ, 28: 42-49. https://doi.org/10.1264/jsme2.ME12085

44. Kruse J, Eckhardt KU, Regier T, Leinweber P (2011). TG-FTIR, LC/MS, XANES and Py-FIMS to disclose the thermal decomposition pathways and aromatic $\mathrm{N}$ formation during dipeptide pyrolysis in a soil matrix. J Anal Appl Pyrol, 90: 164-173. https://doi.org/10.1016/j.jaap.2010.12.002

45. Shen J, Igathinathane C, Yu M, Pothula AK (2015). Biomass pyrolysis and combustion integral and differential reaction heats with temperatures using thermogravimetric analysis/differential scanning calorimetry. Bioresource Technol, 185: 89-98. https://doi.org/10.1016/j.biortech.2015.02.079

46. Mayer LM, Schick LL, Hardy KR, Wagai R, Mccarthy J (2004). Organic matter in small mesopores in sediments and soils. Geochim Cosmochim Ac, 68: 3863-3872. https://doi.org/978-3-319-10394-5

47. Yamamoto T, Goto I, Kawaguchi O, Minagawa K, Ariyoshi E, Matsuda O (2008). Phytoremediation of shallow organically enriched marine sediments using benthic microalgae. Mar Pollut Bull, 57: 108115. https://doi.org/10.1016/j.marpolbul.2007.10.006

48. Xue JC, He M, Wu CF, Zhang ZY, Tan L (2020). Adaptable plants for acidic wastewater sediment of copper sulfide mines. Environ Eng Manage J, 19:1475-1480.

https://doi.org/10.30638/EEMJ.2020.137

49. Li Y, Luo C, Lin X, Li K, Pu WF (2020). Characteristics and properties of coke formed by lowtemperature oxidation and thermal pyrolysis during in situ combustion. Ind Eng Chem Res, 59: 2171-2180. https://doi.org/10.1021/acs.iecr.9b05635

50. Magdziak Z, Gąsecka M, Goliński P, Mleczek M (2015). Phytoremediation and environmental factors. Phytoremediation, pp: 45-55

51. Bai Y, Zhou Y, Gong J (2021). Physiological mechanisms of the tolerance response to manganese stress exhibited by Pinus massoniana, a candidate plant for the phytoremediation of Mncontaminated soil. Environ Sci Pollut R, 28: 45422-45433. https://doi.org/10.1007/s11356-02113912-8

52. Zhu GG, Xiao HY, Guo QJ, Song B, Zheng GD, Zhang ZY, Zhao JJ, Okoli CP (2018). Heavy metal contents and enrichment characteristics of dominant plants in wasteland of the downstream of a lead-zinc mining area in Guangxi, Southwest China. Ecotox Environ Safe, 151: 266-271. https://doi.org/10.1016/j.ecoenv.2018.01.011

53. Wpc A, Wvdsp A, Damg A, Ommt B, Cbda C, Arf A (2020). Phytoremediation potential of Khaya ivorensis and Cedrela fissilis in copper contaminated soil. J Environ Manage, 268. https://doi.org/10.1016/j.jenvman.2020.110733

54. Karimyan K, Alimohammadi M, Maleki A, Yunesian M, Foroushani AR (2020). The mobility of arsenic from highly polluted farmlands to wheat: Soil-Plant transfer model and health risk assessment. 


\section{Figures}

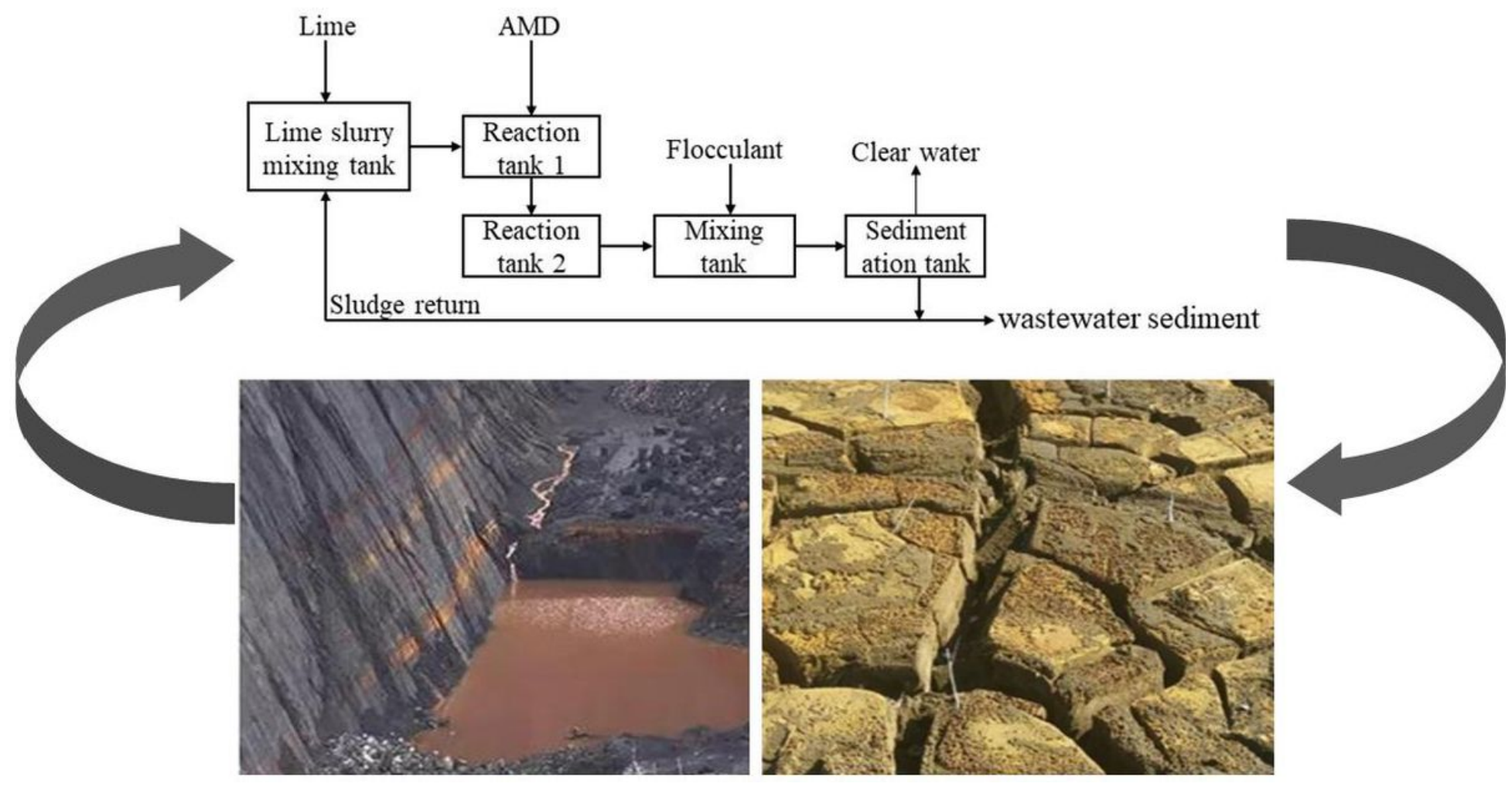

\section{Figure 1}

Flow chart of the High-density Sludge process. The acidic mine wastewater is added to the lime mud mixing tank, passes through reaction tanks 1 and 2, and the flocculant is poured into it and flows into the sedimentation tank for precipitation to realize the separation of mud and water. The supernatant is discharged out after overflow, a part of the sedimentation tank bottom sludge is returned to the bottom sludge-lime mixing tank. The excess sediment is discharged to the sludge tank, directly pumped from the bottom of the sedimentation tank to the filter press room for pressure filtration, and then discharged to the dumpsite Pileup. 

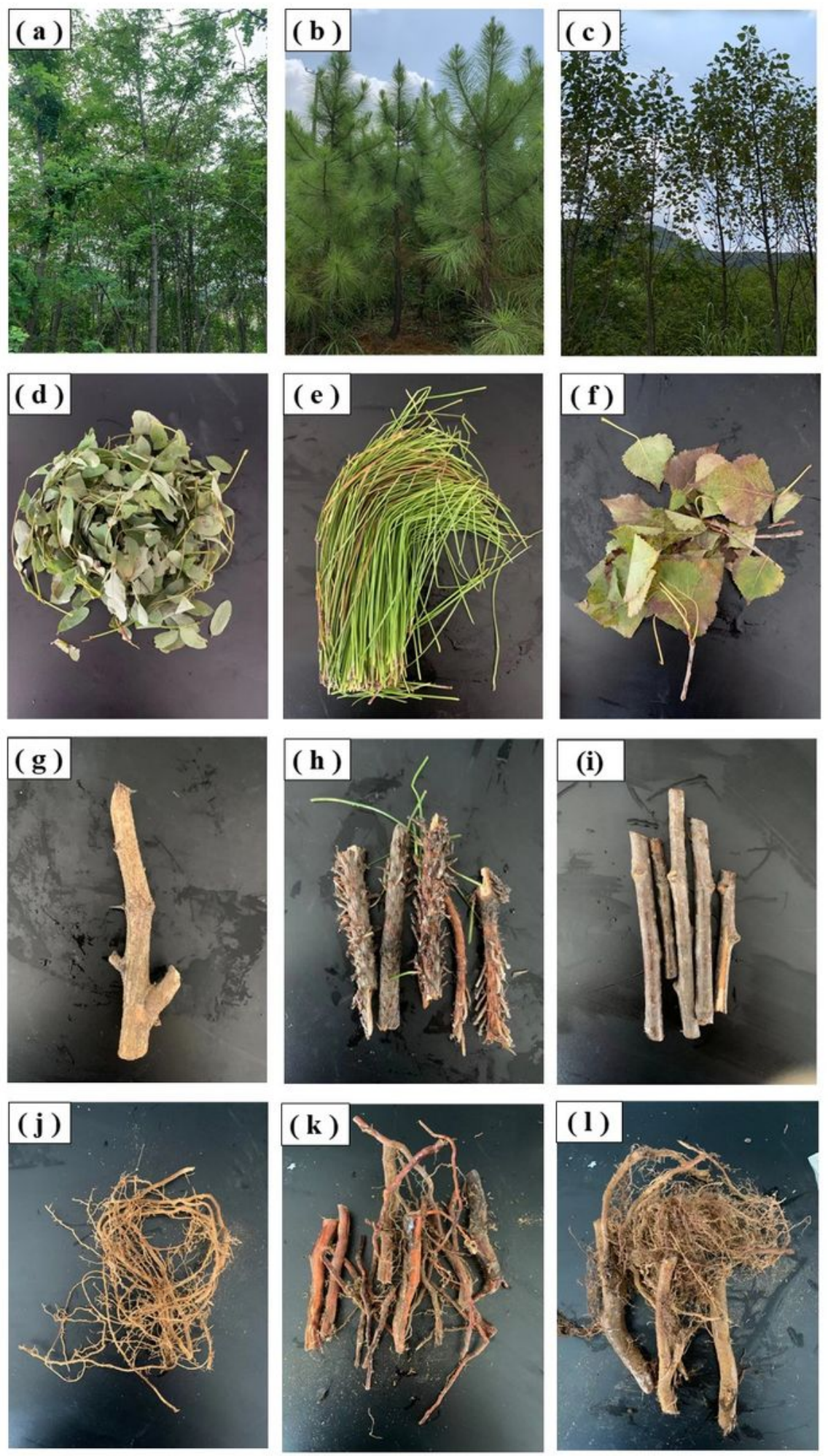

\section{Figure 2}

Species planted and plant roots stem and leave samples grown in the experimental area. (a), (d), (g) and (j) are black locust, black locust leaf, black locust stem, and black locust root, respectively. (b), (e), (h), combined with (k) are slash pine, slash pine leaf, slash pine stem, and slash pine root, respectively. (c), (f), (i), (I) are Chinese white poplar, Chinese white poplar leaf, Chinese white poplar stem, and Chinese white poplar root, respectively. 


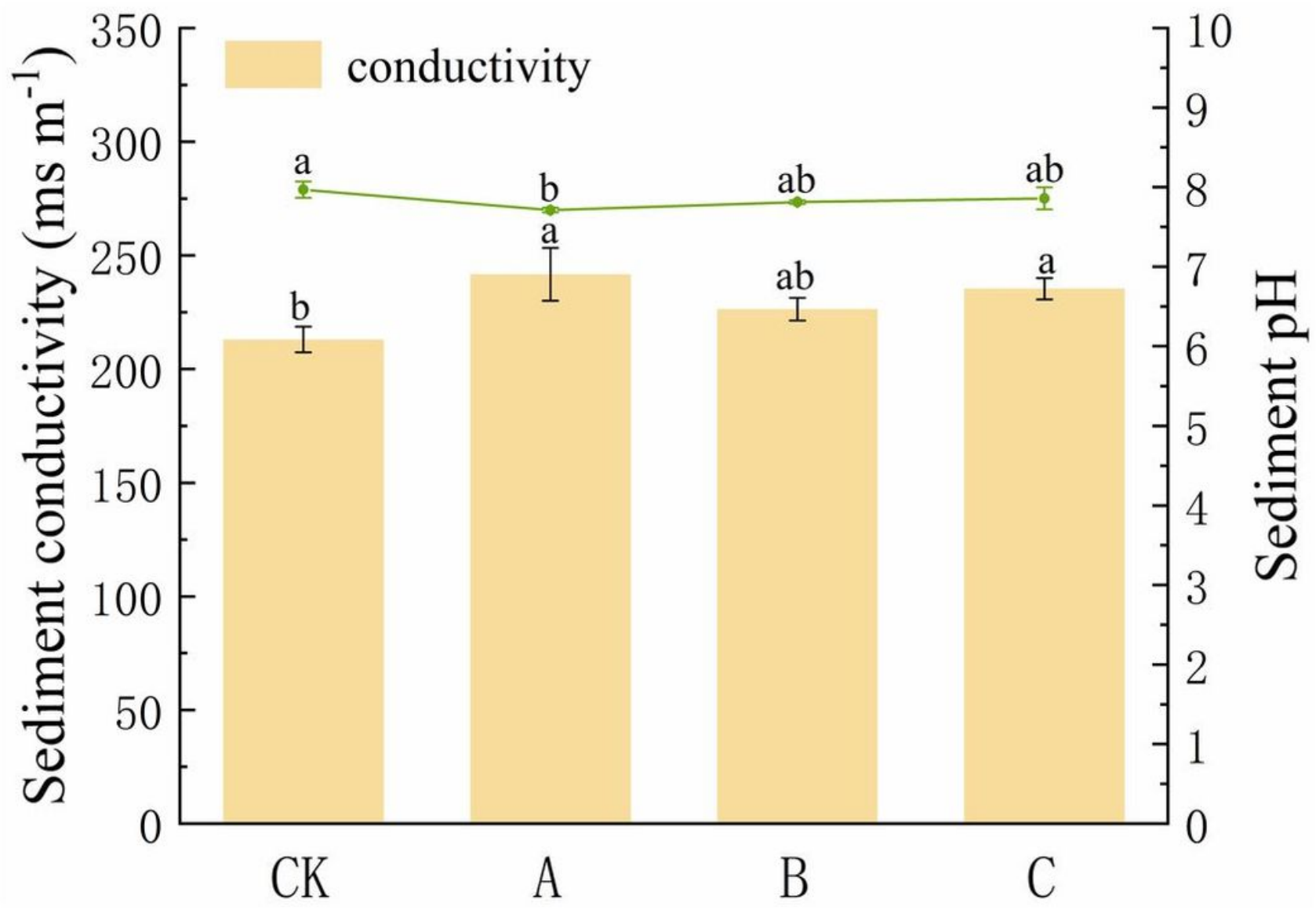

Figure 3

Effects of different phytoremediation on $\mathrm{pH}$ value and conductivity of HDS sediment. Values are means \pm standard error. According to Duncan's multiple range test, the data followed by a different letter are significantly different $(P \leq 0.05)$. CK, the sediment without phytoremediation; $A$, planted black locust; $B$, planted slash pine; $\mathrm{C}$, planted Chinese white poplar. 


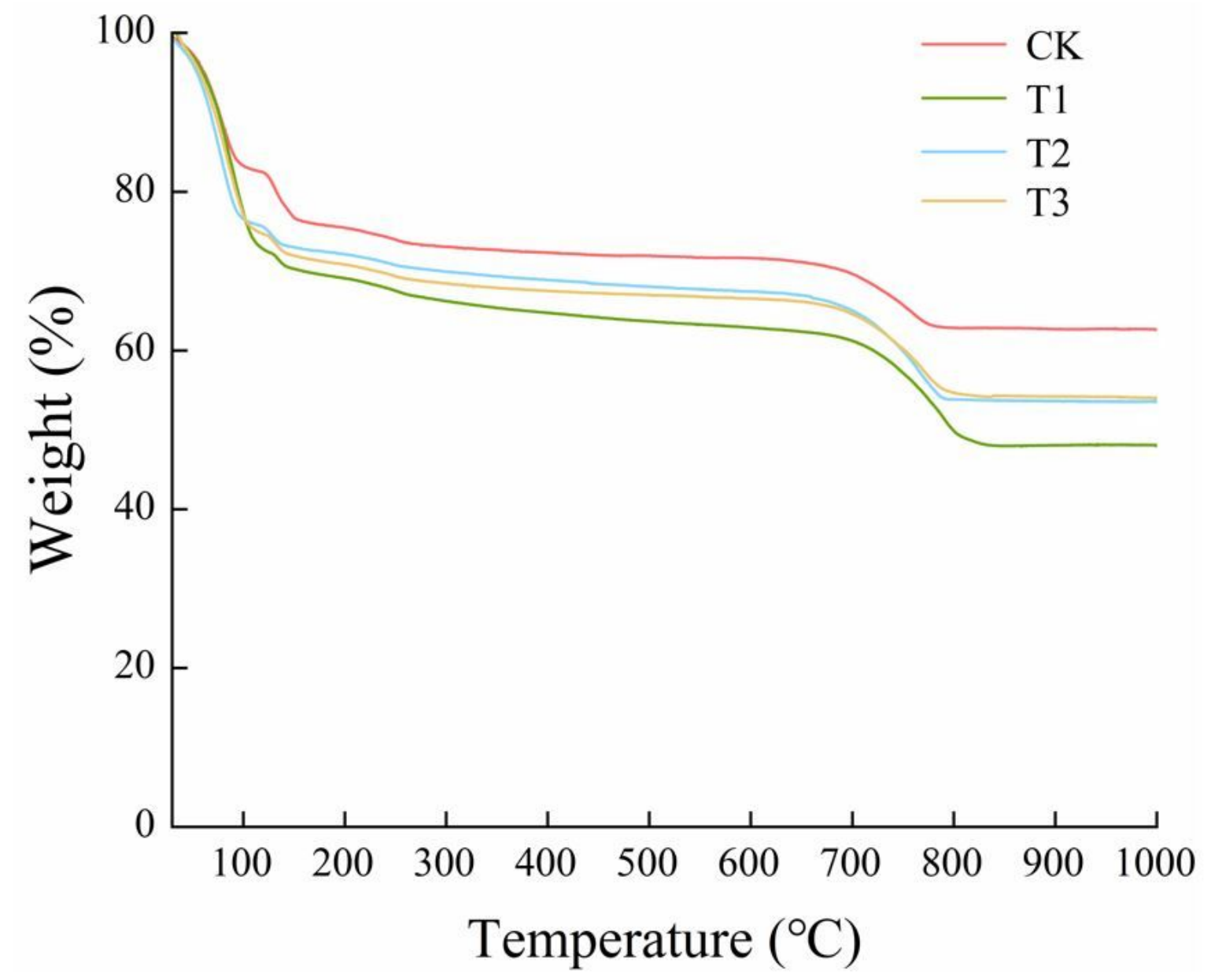

Figure 4

Thermogravimetric (TG) curves of HDS sediment after phytoremediation. CK, the sediment without phytoremediation; T1, planted black locust; T2, planted slash pine; T3, planted Chinese white poplar. 

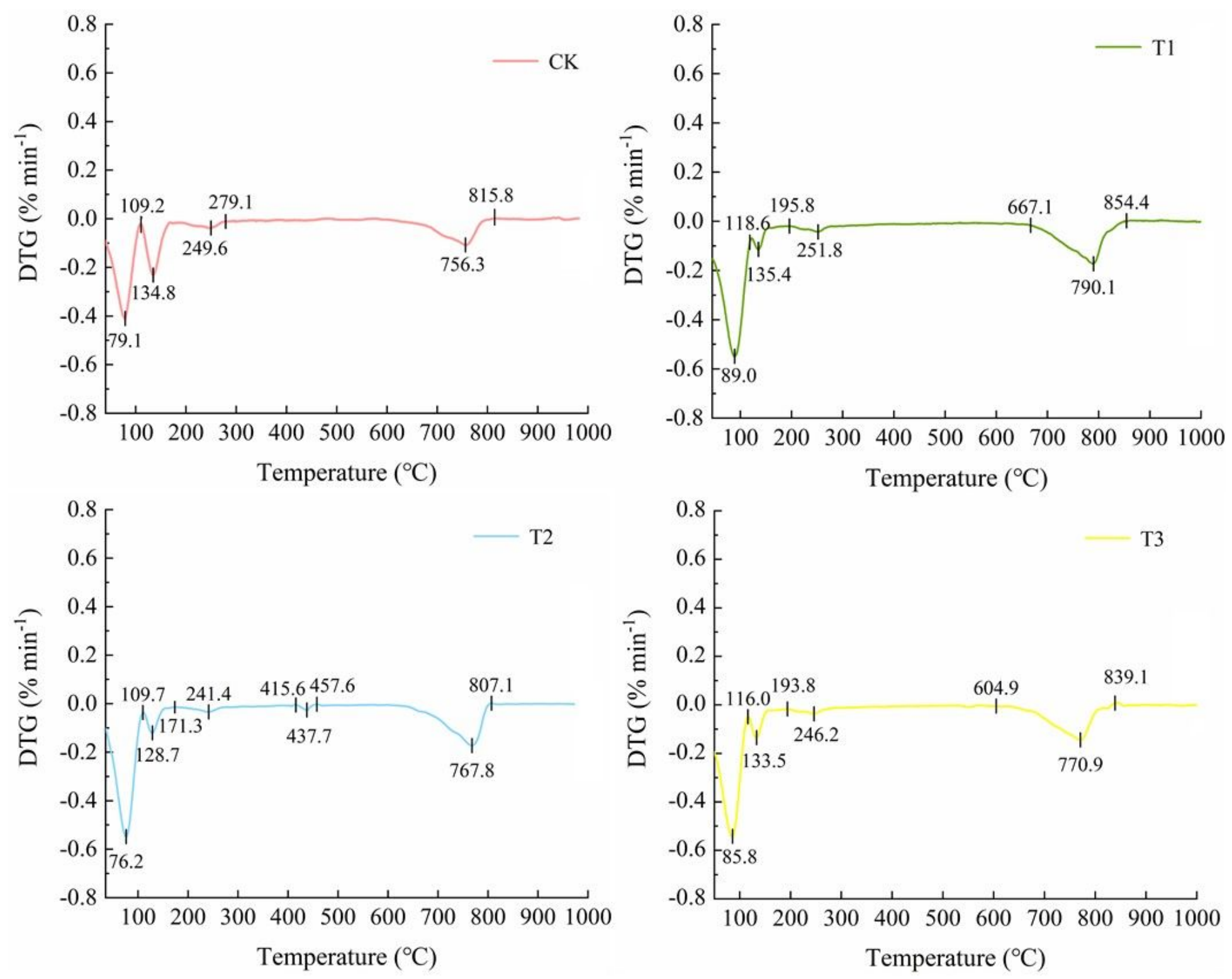

\section{Figure 5}

The derivative curves of mass loss (DTG) curves of HDS sediment after phytoremediation. CK, the sediment without phytoremediation; T1, planted black locust; T2, planted slash pine; T3, planted Chinese white poplar. 